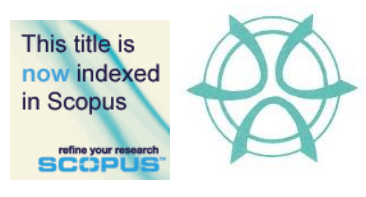

PLANNING MALAYSIA:

Journal of the Malaysian Institute of Planners

VOLUME 17 ISSUE 2 (2019), Page 352 - 360

\title{
QUALITY OF LIFE ASSESSMENT BASED ON ECONOMIC WELL- BEING PERSPECTIVE: A CASE STUDY OF JOHOR BAHRU AND PETALING, SELANGOR
}

\author{
Mariana Mohamed Osman ${ }^{1}$, Nur Farhanah Rosli $^{2} \&$ Noor Suzilawati Rabe ${ }^{3}$ \\ 1,2,3 Kuliyyah of Architecture and Environmental Design \\ INTERNATIONAL ISLAMIC UNIVERSITY MALAYSIA
}

\begin{abstract}
The definition of quality of life is varied. Different individuals may perceive the quality of life in a different form of other individuals. Over more than four decades, Malaysia has made remarkable achievements regarding its economic growth as well as its socio-economic development. Numerous factors have been identified that may influence the quality of life of the people according to their personal preferences. This article assessed the perception of 100 respondent's lives in two major cities in Malaysia namely Johor Bharu and Petaling. These cities are also the major district in Johor Darul Takzim and Selangor Darul Ehsan. These study also would be focusing on the economic well-being of the individual. The economic individual is economic capacity, transportation, living condition and educational satisfaction.
\end{abstract}

Keyword: Quality of life, Economic well-being, Selangor, Johor 
PLANNING MALAYSIA

Journal of the Malaysia Institute of Planners (2019)

\section{INTRODUCTION}

Improving the quality of life (QOL) of the itizen has always been the main focus of the Malaysian government and it has been one of the main agendas in the 11th Malaysia Plan 2016-2020. Generally, QOL is about the extent to which human needs are fulfilled concerning their perception of subjective well-being. Thus, it is the role of policymakers and professionals to provide opportunities for people to be able to meet their desired well-being (Costanza et al., 2005). The World Health Organization Quality of Life group define QOL as 'individual's perception of their position in life in the context of the culture and value systems in which they live and with their goals, expectations, standards and concerns' (Phillips, 2006, p.23). Similarly, several authors (Zainal et al., 2012; Gilgeous, 1998) see QOL as the satisfaction of people over various dimensions including material, education, security, physical and living environment that affected by their perception on what they refer as the ideal life. Serag El-Din et. al (2012), described the quality of life as a complex concept that might be defined by various disciplinary. The term 'quality of life' is used solely to describe some physical features, but it describes all types of relationship, dynamics and the reticular relationship that relates to physical features.

\section{LITERATURE REVIEW}

The word 'quality' as defined by Oxford Dictionary refers to a standard of something that could be measured against things of a similar kind. In other words, it is the degree of excellent on something. Whilst, quality of life as also encompassing personal advancements, a healthy lifestyle, access and freedom to pursue knowledge, and attainment to a standard of living which surpasses the fulfilment of the basic and psychological needs of the individual in order to achieve social well-being compatible with the nation's aspirations (Economic Planning Unit, 2004). Other than that, quality of life also defines as an individual's perception of their position in life in the context of the culture and value systems in which they live and about their goals, expectations, standards and concerns. It is a broad-ranging concept affected in a complex way by the person's physical health, psychological state, personal beliefs, social relationships and their relationship to salient features of their environment (World Health Organization, 2012). QOL is the subject of academic debate in various fields particularly in economics, the field of happiness studies, a research area shared with psychologists and sociologists (Rabe, Osman, Bachok, Rosli, \& Abdullah, 2018).

The concept of quality of life is complex because it includes multidimensional of contributory facets such as housing, education, work and environment (Garcia-Mira, Uzzell, Real, \& Romay, 2005; Serag El Din et al., 2012). Serag El Din et al. (2012) also agree that quality of life requires multiple approaches from different theoretical perspectives. However, Yahaya (2015) explains that the rapid economic growth reflects the high quality of life for the 
Mariana Mohamed Osman, Nur Farhanah Rosli \& Noor Suzilawati Rabe

Perceiving quality of life in terms of economic well-being: Johor Bahru vs Petaling

people in a country where all population should have an equal opportunity to enjoy the amenities provided by their government.

Generally, Malaysia Quality of Life (MQLI) report was first produced in 1999 until the year 2011. Throughout these years, the major changes in the indicators are including the growing of 10 measurements (in 1999) to 11 major measurements in 2011. Meanwhile, in 2013, the quality of life measurement report was rebranded and introduced as Malaysia Well-Being Index Report consisting of 14 major quality of life measurements. The latest report was more organized with the classification of both economic and social well-being. Components in Economic well-being namely transportation, communications, education, income and distribution and working life.

\section{RESEARCH METHODOLOGY}

This study involves the economic well-being sectors in two major districts in Malaysia namely Petaling Jaya district and Johor Bahru district. Petaling is one of the major districts in Selangor meanwhile Johor Bahru is the capital city of Johor. Both Johor and Selangor are among the states in Malaysia that experienced rapid development progress. According to the Department of Statistic Malaysia (2016), Johor hold the highest GDP in Malaysia as compared to the other states. In terms of population number, the population in Johor Bahru was $1,345,191$ whilst Petaling was 1,782,375 (DOSM, 2016).

In this research, the method used was quantitative and qualitative. For qualitative research, review of literature, journals, published data from various secondary sources was employed. Driven by the objective formulated based on qualitative analysis, a quantitative method was used to answer the research question. Through questionnaire survey form, the questions were designed to measure respondents' scale of preferences on how they perceived their current economic well-being quality. Random sampling was adopted in selecting the number of respondents from both districts. However, due to the low number of participation from the target population, a convenient sampling method was used that was based on the availability and willingness of respondents. A total of 100 respondents were chosen from both districts and a scale using of 0-10 weas used to measure their perception towards the quality of life.

Specifically, in referring to the Malaysian well-being Index Report, this study focusses on the elements in economic well-being in this study namely economic capacity, transportation, living condition and education satisfaction. 
PLANNING MALAYSIA

Journal of the Malaysia Institute of Planners (2019)

\section{FINDINGS AND ANALYSIS}

\section{Socio-Demographic Result}

Table 1 Socio-demographic in Johor Bharu and Petaling, Selangor

\begin{tabular}{|c|c|c|c|}
\hline \multicolumn{2}{|c|}{ Socio-demographic } & JB (\%) & Petaling (\%) \\
\hline \multirow{2}{*}{ Gender } & Female & 58 & 58 \\
\hline & Male & 42 & 42 \\
\hline \multirow{4}{*}{ Race } & Malay & 26 & 79 \\
\hline & Chinese & 71 & 16 \\
\hline & Indian & 2 & 5 \\
\hline & Others & 1 & 0 \\
\hline \multirow{4}{*}{ Age } & Less than $20 \mathrm{y} / \mathrm{o}$ & 3 & 0 \\
\hline & $21-40 \mathrm{y} / \mathrm{o}$ & 46 & 81 \\
\hline & $41-60 \mathrm{y} / \mathrm{o}$ & 40 & 17 \\
\hline & $61 \mathrm{y} / \mathrm{o}$ and above & 11 & 2 \\
\hline \multirow{5}{*}{ Marital status } & Single & 3 & 41 \\
\hline & Married & 33 & 57 \\
\hline & Divorced & 41 & 2 \\
\hline & Widowed & 19 & 0 \\
\hline & Others & 4 & 0 \\
\hline \multirow{11}{*}{ Household income } & RM 1,000 and below & 0 & 2 \\
\hline & RM 1,001- 2,000 & 13 & 15 \\
\hline & RM 2,001-3,000 & 17 & 31 \\
\hline & RM 3,001-4,000 & 4 & 12 \\
\hline & RM 4,001-5,000 & 13 & 9 \\
\hline & RM 5,001-6,000 & 12 & 12 \\
\hline & RM 6,001-7,000 & 13 & 2 \\
\hline & RM 7,001-8,000 & 20 & 1 \\
\hline & RM 8,001-9,000 & 4 & 0 \\
\hline & RM 9,001-10,000 & 1 & 6 \\
\hline & RM 10,000 and above & & 10 \\
\hline \multirow{5}{*}{ Educational level } & Primary school & 68 & 3 \\
\hline & Secondary school & 26 & 20 \\
\hline & STPM/ Certificate/ diploma & 5 & 35 \\
\hline & Degree & 1 & 37 \\
\hline & Master & 0 & 5 \\
\hline
\end{tabular}

Table 1 presents the socio-demographic background of 100 respondents from Johor Bharu and Petaling districts. With 58\% of female respondents and $42 \%$ male respondents, it can be seen that a similar number of gender were recorded in both districts. For Johor Bharu, majority of the respondents who have participated in the survey were Chinese with $71 \%$. Contrarily, $79 \%$ of the respondents in Petaling were majority Malay. The majority who participated in the survey were from respondents who were aged between 18 years old and above. Both districts recorded the majority of respondents were from the age 
Mariana Mohamed Osman, Nur Farhanah Rosli \& Noor Suzilawati Rabe

Perceiving quality of life in terms of economic well-being: Johor Bahru vs Petaling

group of 21 to 40 years old (46\% Johor Bharu district and $81 \%$ Petaling district). Meanwhile, the second-highest age group for both districts were 41-60 years old with a percentage of $40 \%$ and $17 \%$ respectively. Majority of the respondents in Johor Bharu were divorced meanwhile 57\% out of 100 respondents from Petaling are married. Out of 100 respondents, $68 \%$ of respondents in Johor Bharu attended primary school. Meanwhile, for Petaling, the highest percentage with $37 \%$ claimed they had a bachelor degree.

Comparison on Relative Importance Index (RII): Johor Bharu vs Petaling

Table 2 RII comparison of economic well-being

\begin{tabular}{|l|r|r|}
\hline \multirow{2}{*}{ Elements Economic capacity } & \multicolumn{1}{c|}{ RII (Rank) } \\
\cline { 2 - 3 } & JB & Petaling \\
\hline Household income satisfaction & $0.28(4)$ & $0.63(2)$ \\
\hline Job satisfaction & $0.28(4)$ & $\mathbf{0 . 6 7}(\mathbf{1})$ \\
\hline Monthly income sufficiency & $0.49(2)$ & $0.55(4)$ \\
\hline No problem in commuting cost & $\mathbf{0 . 7 4}(\mathbf{1})$ & $0.61(3)$ \\
\hline Having no problem to buy properties & $0.44(3)$ & $0.40(5)$ \\
\hline \multicolumn{2}{|c|}{$0.67(2)$} & $0.77(1)$ \\
\hline Owning private vehicles & $0.69(1)$ & $0.45(2)$ \\
\hline Often use public transportation & $0.63(3)$ \\
\hline Preference use public transportation in daily & $0.64(3)$ & 0.43 condition \\
\hline \multicolumn{2}{|c|}{$0.63(3)$} & $0.74(2)$ \\
\hline Living place satisfaction & $0.64(2)$ & $0.58(3)$ \\
\hline Would not mind neighbouring with a foreigner & $0.68(1)$ & $0.76(1)$ \\
\hline House located in a strategic place Education satisfaction & $0.68(1)$ & $0.44(4)$ \\
\hline PWD's facilities are adequate in my house area & $0.66(3)$ & $0.73(2)$ \\
\hline \multicolumn{2}{|c|}{$0.63(4)$} & $0.58(4)$ \\
\hline Satisfied with current educational level & $0.85(1)$ & $0.92(1)$ \\
\hline Wish to continue study to another level & $0.72(2)$ & $0.68(3)$ \\
\hline $\begin{array}{l}\text { Supportive towards children/spouse/ siblings to continue } \\
\text { study at another level }\end{array}$ & Source: Author calculation
\end{tabular}

Relative Importance Index (RII) was calculated based on respondents' scale of preferences in the survey form. For RII, the highest values indicated the highest the scale chose by respondents in measuring their economic wellbeing. Referring to Table 2 above, the highest RII values for each district are different, in which for JB the highest values that ranked as the first is 0.74 of satisfaction on commuting cost while 0.67 ranked as first for Petaling is satisfaction on current employment. Furthermore, the second-highest value for Petaling ranked as the second is satisfaction related to household income with RII value of 0.63. In contrast, the second economic well being ranked based on satisfaction for JB is relate to monthly income sufficiency with RII value of 0.49 . 
Meanwhile, the least preferred or representing the highest dissatisfaction on economic well being is the satisfaction on buying properties with 0.40 for Petaling, while household income and job satisfaction are ranked as the least favoured indicators with RII values of 0.28 by respondents from Johor Bahru.

\section{Economic well-being against household income of the respondents}

Table 3 Economic capacity against household income

\begin{tabular}{|l|c|c|c|c|}
\hline \multirow{2}{*}{ Economic capacity } & \multicolumn{4}{|c|}{ Household income } \\
\cline { 2 - 5 } & \multicolumn{2}{|c|}{ JB } & \multicolumn{2}{c|}{ Petaling } \\
\cline { 2 - 5 } & CC & P-value & CC & P-value \\
\hline Household income satisfaction & -.152 & .131 & $.238^{*}$ & .017 \\
\hline Job satisfaction & -.170 & .090 & $.262^{* *}$ & .009 \\
\hline Monthly income sufficiency & .009 & .927 & $.270^{* *}$ & .007 \\
\hline No problem in commuting cost & .044 & .663 & $.369^{* *}$ & .000 \\
\hline Having no problem to buy properties & .028 & .784 & $.345^{* *}$ & .000 \\
\hline
\end{tabular}

Table 3 indicates the Pearson correlation result between the household income of the respondents against the economic capacity of 100 respondents in both Petaling and Johor Bahru. There is no relationship involved between the two variables mentioned in Johor Bharu as the P-Value more than 0.05 . Whilst, the $\mathrm{P}$-value in all economic capacity variables in Petaling district resulted in less than 0.05 which the null hypothesis stated no relationship between the variables cannot be rejected. Referring to Guildford's rules of thumb, household income satisfaction $\left(0.262^{* *}\right)$, job satisfaction $\left(0.262^{* *}\right)$ and monthly income sufficiency $\left(0.270^{* *}\right)$ having a very low positive relationship with the household income variable. On the other hand, having no problem with commuting cost $\left(0.369^{* *}\right)$ and having no problem to buy properties $\left(0.345^{* *}\right)$ resulted in a low positive relationship with household income. Hence, it can assume that the higher the respondents' income, the higher the preference on household income satisfaction, job satisfaction, monthly income sufficiency, having no problem in commuting cost and buying additional properties by the respondents in Petaling district.

Table 4 Household income against transportation

\begin{tabular}{|l|c|c|c|c|}
\hline \multirow{2}{*}{ Transportation } & \multicolumn{4}{|c|}{ Household income } \\
\cline { 2 - 5 } & \multicolumn{3}{|c|}{ JB } & \multicolumn{2}{c|}{ Petaling } \\
\cline { 2 - 5 } & $\mathrm{CC}$ & P-value & $\mathrm{CC}$ & P-value \\
\hline Owning private vehicles & .109 & .370 & .058 & .566 \\
\hline Often use public transportation & .047 & .702 & -.129 & .200 \\
\hline $\begin{array}{l}\text { Preference use public } \\
\text { transportation in daily }\end{array}$ & .119 & .326 & -.024 & .809 \\
\hline
\end{tabular}

Table 4 portrays Pearson correlation result of household income and transportation satisfaction by the respondents. All of the P-Values are more than 
Mariana Mohamed Osman, Nur Farhanah Rosli \& Noor Suzilawati Rabe

Perceiving quality of life in terms of economic well-being: Johor Bahru vs Petaling

0.05 which indicate the null hypothesis stated there is no relationship between variable cannot be accepted.

Table 5 Household income against the living condition

\begin{tabular}{|l|c|c|c|c|}
\hline \multirow{2}{*}{ Living condition } & \multicolumn{4}{|c|}{ Household income } \\
\cline { 2 - 5 } & \multicolumn{3}{|c|}{ JB } & \multicolumn{2}{c|}{ Petaling } \\
\cline { 2 - 5 } & CC & P-value & CC & P-value \\
\hline Living place satisfaction & .015 & .902 & .136 & .177 \\
\hline $\begin{array}{l}\text { Would not mind neighbouring with } \\
\text { foreigner }\end{array}$ & .138 & .255 & $.219 *$ & .028 \\
\hline House located in strategic place & .031 & .802 & .039 & .702 \\
\hline $\begin{array}{l}\text { PWD's facilities are adequate in my } \\
\text { house area }\end{array}$ & .021 & .863 & $.294 * *$ & .003 \\
\hline
\end{tabular}

Table 5 shows the Pearson correlation result for living condition against household income. Generally, P-value for living condition elements against household income in Johor Bharu is more than 0.05 which the null hypothesis stated there is no relationship between variables can be accepted. Similar result shared by the living place satisfaction and strategic house location for Petaling District. On the other hand, the $\mathrm{P}$-value of having a foreigner as a neighbour $(\mathrm{P}$ value: 0.028 ) and PWDs' facilities adequacy (P-value: 0.003 ) in Petaling district are less than 0.05 which the null hypothesis stated there is no relationship between variables can be rejected. Regarding Guilford's rules of thumb, the relationship classified as very low positive relating. It can be assumed that the lower the household income, lower the living condition preferences.

Table 6 Household income against educational satisfaction

\begin{tabular}{|l|c|c|c|c|}
\hline \multirow{2}{*}{ Educational satisfaction } & \multicolumn{4}{|c|}{ Household income } \\
\cline { 2 - 5 } & \multicolumn{2}{|c|}{ JB } & \multicolumn{2}{c|}{ Petaling } \\
\cline { 2 - 5 } & $\mathrm{CC}$ & P-value & CC & P-value \\
\hline Satisfied with current educational level & .114 & .349 & .071 & .480 \\
\hline Wish to continue study to another level & .124 & .306 & .036 & .719 \\
\hline $\begin{array}{l}\text { Supportive towards children/spouse/ } \\
\text { siblings to continue study in another } \\
\text { level }\end{array}$ & $.286^{*}$ & .017 & .141 & .161 \\
\hline $\begin{array}{l}\text { Malaysia educational system generate } \\
\text { ideas of students }\end{array}$ & $.346^{* *}$ & .003 & -.141 & .163 \\
\hline
\end{tabular}

Table 6 shows the Pearson correlation results in household income against educational satisfaction. Overall, result in JB district shows, there are two variables with $\mathrm{p}$-value less than 0.05 namely supportive towards children/ spouse/ siblings to continue study in another level (p-value: 0.017) and Malaysia educational system generate ideas of the student (p-value: 0.003 ). This indicates 
that the null hypothesis stated that there is no relationship between these variables can e rejected.

On the other hand, p-value in all educational satisfaction variables in Petaling is more than 0.05 which the null hypothesis stated there is no relationship between variables can be accepted.

\section{CONCLUSION}

In conclusion, from the RII result, it shows that the respondents in both major cities in Malaysia perceiving their quality of life in terms of economic well-being. It can be seen that both cities perceiving the quality of life in their form which resulted in the different result for both cities. From the result also, it can be assumed that even though respondents in Johor Bharu least satisfied with the household income and their job, respondents in Petaling perceiving both of these elements as the most satisfying elements in economic capacity. Meanwhile, when the respondents in Johor Bharu satisfied with their monthly commuting cost, respondents in Petaling perceive it the other way around.

Hence, it can be concluded that to distinguish the quality of life in any terms it is based on the individual or the community itself since the quality of life contains border concept which affects the individual in terms of surrounding, the economy as well as the community. Quality of life study should be focusing on cross-cultural and regional differences or similarities in different parts of the world (Mohit, 2014). While economic growth leads to improvements in the quality of life, a better quality of life enables the population to participate more fully in economic development (Holdstock \& Rowson, 2005).

\section{REFERENCES}

Costanza, R. et al. (2005). Quality of life: An approach integrating opportunities, human needs, and subjective well-being. Ecological Economics, 61(1), 267-276.

Economic Planning Unit (2004). Malaysia Quality of Life Report, 2004.

Garcia-Mira, R., Uzzell, D. L., Real, J. E., \& Romay, J. (2005). Housing, space and quality of life.

Gilgeous, V. (1998). The quality of work life. Integrated Manufacturing System, 9(1), 173-181.

Holdstock, D., \& Rowson, M. (2005). Malaysia: Achieving the Millennium Development Goals: Successes and challenges. United Nations Country Team, Malaysia.

Lora, E. et al. (2010). The quality of life in Latin American cities: Markets and perception. The Inter-American Development Bank.

Mohit, M. A. (2014). Present trends and future directions of quality-of-life. Procedia Social and Behavioral Sciences, 153, 655-665.

Phillips D. (2006) Quality of life: Concept, policy and practice. London: Routledge

Rabe, N. S., Osman, M. M., Bachok, S., Rosli, N. F., \& Abdullah, M. F. (2018). Perceptual study on conventional quality of life indicators. Planning Malaysia Journal, 16(5), 303-313. 
Mariana Mohamed Osman, Nur Farhanah Rosli \& Noor Suzilawati Rabe

Perceiving quality of life in terms of economic well-being: Johor Bahru vs Petaling

Serag el din, H. et al. (2013). Principles of urban quality of life for a neighborhood. $H B R C$ Journal, 9(1), 86-92.

WHO. (2012). WHOQOL. Retrieved from http://www.who.int/healthinfo/ global_burden_disease/estimates/en/index1.html

Yahaya, A. S., \& Selvaratnam, D. P. (2015). Relationship between Malaysian quality of life and gross domestic product. Kuala Lumpur International Business, Economics and Law Conference 6, 3, 978-967-11350-4-4.

Zainal, N. R., Kaur, G., Ahmad, N. A., \& Khalili, J. M. (2012). Housing conditions and quality of life of the urban poor in Malaysia. Procedia - Social and Behavioral Sciences, 50, 827-838

Received: $12^{\text {th }}$ January 2019. Accepted: $2^{\text {nd }}$ August 2019 